\title{
A New Approach To Teaching Business Writing: Writing Across The Core - A Document Based Curriculum
}

\author{
Teresa D. Hutchins, Ramapo College of New Jersey, USA
}

\begin{abstract}
This paper describes the transition that the Anisfield School of Business of Ramapo College of New Jersey made from a conventional Writing Across the Curriculum approach to a Writing Across the Business Core approach. The impetus for the change is explained as well as the creation and design of the program. The document driven program is analyzed, with special emphasis on faculty buy in. The rationale for the documents chosen is provided as is the logic behind the course sequence. The paper concludes with the results of the first assessment of the program.
\end{abstract}

Keywords: Assessment; Writing Across The Curriculum; Document Driven; Writing Program

\section{INTRODUCTION}

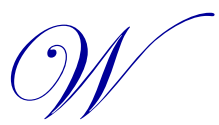

ithout too much effort, it is easy to find articles in the popular press about the appalling writing skills of students, and new entrants into the work force. They have provocative titles such as: This Embarrasses You and I, Why Can't MBA Students Write, the Literate Business Student and Teaching Taco Bell's Canon. ${ }^{l}$ The unifying theme in all of these articles is the sub-par state of Generation X and Y's writing skills. The articles contain numerous examples of writing errors and they are presented in a humorous manner. As much fun as it is to identify errors in grammar and logic by others, it is much less fun to be the one to provide a solution. This article describes the attempt of one undergraduate business school to improve their students' communication skills by utilizing writing across the curriculum strategy.

\section{BACKGROUND}

The original writing program in the Anisfield School of Business at Ramapo College of New Jersey was a conventional layered writing intensive design. The college had adopted writing across the curriculum approach in which students would take three general education writing intensive classes and three upper level writing intensive classes in their major. The business school also had a specific communications' learning goal which stated that students should be able to compose well-written business documents. The writing intensive assignments in the business school ranged from the standard research paper to cases to position papers. With the first comprehensive assessment of writing in the business school, the flaws in this writing intensive program and in its implementation were revealed. Three areas were noted: 1) students had little proficiency in the concise style of business writing, 2) faculty did not have a consensus as to which business documents to focus on and 3) individual faculty who had responsibility for delivering a class for which writing was a learning goal felt overburdened. As a result a new writing program was created.

\footnotetext{
${ }^{1}$ The articles in order referenced are: This Embarrasses You and I Grammar Gaffes Invade the Office in an Age of Informal Email, Texting and Twitter by Sue Shellenbarger, Wall Street Journal, June 19, 2012, Why Can't M.B.A. Students Write by Diana Middleton, Wall Street Journal, March 4, 2011, The Literate Business Student by Wayne Smith BizEd March/April 2011 and Teaching “Taco Bell's Canon” by James E. Courter, Wall Street Journal, July 10, 2012.
} 
The intent of the new program, which was named Business Writing Across the Core (BWAC) was to address the issues identified in the assessment while staying true to the tenets of writing across the curriculum. The Anisfield School of Business (ASB) focused on two principles of WAC: providing instruction in writing and enriching the understanding of course content by writing. As Dana, Hancock and Phillips (2011) have shown in their research, the WAC method has a real benefit in the education of business students. They find an improvement in the quality of student writing as undergraduate's progress through the curriculum. ASB also reexamined the school's specific writing learning goal. The faculty realized that there was no definition of a business document and that many of the writing assignments were standard academic papers. Very often, the audience was not identified, and there was no specificity in the assignments. As Carter Daniel, the director of Business Communication at Rutgers Business School has pointed out, “... most students write poorly because teachers aren't clear about what they should be writing."(2012) The business school was guilty of this accusation. Very often the faculty had assigned a generic writing assignment and not a business document. Moving forward the motivation was to be more intentional with the program, and to focus on conventional business documents.

An additional challenge was to address the outcomes of the assessment. Students scored low in clarity and organization. The assignment was for students to make a recommendation to a client on financial alternatives. Students choose many different formats for responding to this task. Some students developed themes irrelevant to the prompt, others summarized without reaching a conclusion and some students simply supplied bullet points with no supporting information. The major conclusion was that students needed more instruction in the concise informative manner of business.

Another matter was the instructional goal of individual faculty. Some faculty spent considerable time providing guidance for writing instruction, and some faculty assigned writing projects with no instruction. Preparing balance sheets was interpreted by some faculty as a well written business document, while others considered a research paper to be the epitome of writing. It should be underscored that this was a collective failure of the faculty to define a business writing program, and not an individual one. The school had defined a business writing learning goal, but not a strategy for implementation. In addition the business school adopted the same writing across the curriculum as the other schools in the college rather than creating a program that was geared to business students. As was noted by Blummer, Eliason and Fritz (2001) in their article charting the future of writing programs, crafting a writing program should be approached as a pedagogical void which needs to be filled not as a mandatory task from administration (p. 22). ASB had used the program suggested by the administration rather than exploring a strategy that was uniquely suited to the needs of business students.

Finally, after discussing the results of the assessment, it became clear that the faculty teaching the three business writing intensive classes felt tremendous pressure to cover the curriculum content as well as providing writing instruction. They had volunteered to teach the classes, but overtime instructors felt forced to teach them. Positive faculty attitudes towards teaching writing have been noted by Washington (2014) as a key variable in the success of student writing. Along with noting the challenges to teaching non-native English students and the need to instruct students in workplace writing, Washington identifies instructor commitment as a key to producing students with keen writing skills. This commitment had diminished overtime at this institution. An additional faculty issue was that any deficiency in student writing was perceived as a possible deficiency in instruction. Faculty felt judged when students scored poorly in writing assessment. As McEwen (2003) has noted improving student writing is the collective responsibility of all courses and professors. To address both of these issues, ASB decided to embrace a new mantra for improving student writing which relied on a bottom-up approach with shared commitment by all.

\section{The Design Of Business Writing Across The Core}

The Anisfield School of Business decided to take a new approach to fulfilling the Written Communication learning goal; rather than having three classes responsible for delivering this objective, it was decided to adopt writing across the business core. As is common in many business schools, students take a substantial school core, which includes classes from all of the business disciplines. At Ramapo College with four credit classes, students take a minimum of 36 classes to graduate. Students take 15 classes in general business classes and five in their major. The BWAC program embeds writing assignments in ten of the fifteen core classes and focuses on five business documents. Instruction would be more intentional and the work load among the faculty 
would be diffused. Students would hear the message in 10 out of 15 classes that writing is important. Each document would be assigned in a 100/200 level class, and again in a 300/400 level class. The faculty discussed a number of common business documents to consider, and finally agreed on the following: Letter, Memo, Executive Summary, Proposal and Business Case. These five were chosen because they offered students a variety of educational experiences in audience awareness, tone, style and organization. The faculty also had to identify ten out of the fifteen core classes for the documents to be embedded. The primary concern was the relevance of the document to the course content. For example the goal of a Proposal is to present an idea or a plan of action. Consequently classes in which students worked on advocating for a business project were examined. A second consideration was providing content scaffolding for the two course sequence. In Principles of Microeconomics, a one hundred level class, students are first introduced to economic reasoning. A concept is introduced and students apply it to a situation. Cognitive expectations are raised in Corporate Finance, a three hundred level class, and the second class in which a memo is assigned. Students are exposed to a concept, apply it to a situation, and then they are expected to apply quantitative analysis to support their reasoning. A similar thread was established between the other pairs of classes. A final consideration in choosing the ten BWAC classes was equity among the faculty. It was a unanimous decision of the faculty to adopt the BWAC program, and a shared work load was crucial for its acceptance.

Table 1 identifies the five documents in the ten classes and provides a brief description of the conceptual uniqueness for each document.

Table 1: Business Writing Across The Core

\begin{tabular}{lccl}
\hline \multicolumn{1}{c}{ Document } & Introductory Class & Advanced Class & \multicolumn{1}{c}{ Conceptual Distinction } \\
\hline Letter & Business law & Business Ethics & $\begin{array}{l}\text { External document conveying } \\
\text { information, sometimes negative, to an } \\
\text { often unfamiliar audience }\end{array}$ \\
\hline Memo & $\begin{array}{c}\text { Principles of } \\
\text { Microeconomics }\end{array}$ & Corporate Finance & $\begin{array}{l}\text { Internal document providing } \\
\text { information, requesting information or } \\
\text { persuading an audience }\end{array}$ \\
\hline Executive Summary & Managerial Accounting & $\begin{array}{c}\text { International Business } \\
\text { Category }\end{array}$ & $\begin{array}{l}\text { Summary of a larger document or } \\
\text { project }\end{array}$ \\
\hline Proposal & $\begin{array}{c}\text { Principles of Information } \\
\text { technology }\end{array}$ & $\begin{array}{c}\text { Operations Management } \\
\text { Persuasive document to outside audience }\end{array}$ \\
\hline Business Case & Marketing Principles and & Managing Organizational \\
Practices & $\begin{array}{l}\text { Extensive analysis of a business issue } \\
\text { which provides a recommendation }\end{array}$ \\
\hline
\end{tabular}

The business school held a number of meetings to finalize the ten course package, and to establish the flow between the classes. For example, an Executive Summary is an appropriate document only if a larger project or paper is assigned in a class. Managerial Accounting was identified as a logic course for assigning an Executive Summary since students are required to conduct extensive quantitative analysis. Students are expected to conduct balance sheet analysis and to communicate the results of this analysis to non-accountants. The Executive Summary is an ideal document to challenge students to capture their thoughts and convey them in a manner universally understandable. The international category of classes offered an additional opportunity for students to craft an Executive Summary. The unique characteristic of classes in this category is that they are very integrative with the social sciences and humanities. Understanding business in an international setting requires students to comprehend cultural, historical and political nuances, as well as foreign exchange arbitrage and banking regulation. Consequently the classes in this category typically have an extensive research paper or project. Crafting a one page summary of their research is an ideal teaching tool for students are to succinctly summarize information. Choosing the appropriate document for a class, which enhances the academic experience, is the DNA of learning to write in the disciplines.

It should also be pointed out that even though the business core focused on professional documents, traditional student assignments are required in the disciplines. In a survey of the majors, research papers were still required in the majority of the capstone classes. For the two disciplines that did not have a capstone class, research papers were required in multiple upper level classes. Furthermore some majors had required Business Communications classes. 
A common lament in academia is the poor quality of students' writing. Many reasons have been offered to explain this phenomenon such as an emphasis on abbreviated writing and a lack of reading skills by students. As was mentioned in the introduction to this piece, there has also been a series of articles in the business community complaining of the substandard quality of written communication. These are nationwide trends. Upper most for many faculty members is striving to improve the writing skills of the students in front of them. There is an old bumper sticker which says, "Think Globally, Act Locally", which serves as an instructive metaphor for the BWAC program. The troubling state of compositional aptitude for young adults is a national trend. As educators it is understood that one English Composition class is not going to create accomplished writers. Hence the ASB faculty chooses to contribute to improving student writing by focusing on a document driven program. In the best of all possible worlds the motivation would be to make sure that students are equipped with all the tools necessary to become fine writers, but in the face of reality the commitment is to making sure that students can craft five readable business documents.

\section{The Guiding Principles Of BWAC}

With the genesis of the new writing program, a number of principles had to be established. The goals and the rationale for each are as follows:

1. To provide instruction in five specific business documents: As business professionals the faculty felt the most qualified to provide instruction in familiar documents. Acknowledging the importance of writing, and being proficient in its instruction are two entirely different matters. In addition, establishing a finite goal for the students is a concrete achievable goal. Students accomplish a specific task and that improves their overall understanding of course material. As Dynan and Cate (2009) have shown in their research structured assignments improve student knowledge and comprehension of foundation information. The BWAC program combined the skill set and motivation of the faculty with important measurable benchmarks for business students. The faculty would like very much for students to be great writers, but the probability of creating great writers out of twenty year old students is low. Mastering five formula tic documents is achievable.

2. To instruct students in the method of business rhetoric, or critical thinking, for problem-solving: In almost any business or economic situation there are a few key steps: defining an issue, identifying the stakeholders, applying best practice business models to offer insight, providing a recommendation and supporting the recommendations with persuasive arguments and information. By assigning written assignments to articulate these steps the goal of critical thinking will be advancing. As Bechard (1998) noted there is ample opportunity in business classes to teach "research methods, critical thinking and analytical writing" in business schools. (p. 104)

3. To inform students of the types of business writing genres which address different business problems, styles and audience awareness: In addition to providing instruction in specific documents the BWAC program highlights the different types of written communication for professionals. Students are instructed on where and how an Executive Summary is needed, For example, the curriculum emphasizes the importance of voice control in crafting an external letter, and it acknowledges the more causal tone that may be appropriate for an internal memo. As Daniel P. Moore (1994) stated in Exploring Voice in Business Writing: "The use of various perspectives and audiences challenges students to recognize the impact of organizational position in creating and maintaining a voice when writing." (p. 39)

4. To provide a repetitive experience for writing: Each of the five documents would be covered twice in the students' curriculum. Students would be instructed on the design and focus in the first two years and again when they become more academically mature in their final two years. In addition, for a particular class, the document would be assigned more than once, or for longer pieces, a writing process would be established. The writing process could entail pre-writing assignments and/or multiple drafts.

\section{Support For The BWAC Program}

The execution of BWAC requires the commitment of the entire faculty who teach one of the ten classes as well as adjuncts. In any given semester approximately 25 full time faculty and as many as ten adjuncts are teaching a BWAC course. To facilitate their job, a number of steps were put in place. The first was an in-service session for 
faculty entitled: BWAC Writing to Think. The purpose of the session was to clarify the requirements of the BWAC program, to provide a template for each document, to provide suggestions of assignments, to motivate the use of each document and to provide time to brainstorm topics for each document. The template is a document which describes four attributes of each document. They are: Description and Purpose, Form and Style, Audience Awareness and Key Elements. These templates are used as teaching guides for the faculty.

After the initial year of BWAC a second faculty meeting was held in which six faculty members made presentations on their initial experience with BWAC. The sessions covered such concepts as:

- $\quad$ Preparing students for an assignment
- $\quad$ Ideosing workable topics for students
- $\quad$ Integrating correct tone and style for students
- $\quad$ Differentiating synthesis from repetitiveness
Managing the work load for instructors

The session on choosing workable topics for students was particularly informative. The major conclusion was that students had trouble with critical thinking when they choose topics for which they had pre-conceived notions. It became clear through the writing process that students were unable to be analytical when it came to issues, which they already favored such as raising the minimum wage or taxing the wealthiest. The take away from the session was that students had a more enriching educational experience if they were guided to topics for which they came in with an open mind. In addition to providing concrete pedagogical information, the session was a success because it resulted in strengthening the buy in of the faculty for the program, introduced new faculty to BWAC and highlighting best practice techniques for designing writing assignments

In addition to in-house faculty retreats the business school was fortunate to bring in Dr. Chris Anson from North Carolina State University to conduct a writing workshop in April of 2010. Three themes were developed: linking the writing assignment to the learning goals of the class, examining the difference of low stakes vs. high stakes writing assignments, and constructing a process for writing with appropriate points for faculty intervention. Dr. Anson provided relevant business writing assignments which helped to energize the faculty.

Finally an internal web site was created to provide information for faculty. The resource site is still a work in progress but the infrastructure for each of the five business documents exists. For each document the site provides: a handout of key points, examples of assignments, examples of student work, academic articles on business writing pedagogy and examples of well written business documents are included. The faculty is currently working on providing educational video clips on how to construct the five documents. The intent of this project is to support the ongoing efforts of existing faculty members and to provide instruction for new faculty members.

\section{Preliminary Assessment}

The first post BWAC assessment was conducted in spring 2011. Two out of the five documents were assessed: the Proposal from Operations Management and the Memo from Corporate Finance. One hundred and forty student pieces were examined. The assessment was done by the entire business faculty and each piece of student work had two evaluators. A day long retreat was held during which the faculty was broken up into groups to discuss the writing assignment and to engage in an inter-rater reliability session before scoring the student work. The majority of the scoring was completed on the same day.

The unit used Clarity, Mechanics, Organization and Style as the four traits with a target proficiency of eighty percent in the excellent and acceptable category. The results were compiled in the aggregate and for each document. Overall, Clarity and Organization exceeded the target with Mechanics falling slightly short at 77 percent. The most disappointing, but not unexpected result was for Style which only had 65\% of the student work in the acceptable and excellent category. This result was anticipated because in the inter-rater sessions, faculty had debated how to score the persuasive style used in a Proposal. For the most part, faculty felt that students had not used a persuasive enough style in their proposal and instead had adopted a neutral informative tone. The ultimate 
recommendation was for there to be more emphasis on language control in instructing students on writing a proposal. As has been noted by writing scholars such as Reiff (2002) and Jameson (2009), it is much easier to teach clarity than it is to teach tone.

Most interestingly, however, was a side-by-side comparison of the pre and post BWAC assessment. The memo was used since it was similar to the document that was used in the 2008 assessment. The results are summarized in Table 2. Student work was evaluated using the same four conventional writing traits and three performance categories: Unacceptable, Acceptable and Excellent. The results were encouraging.

Table 2: Percentage Of Student Work In Acceptable And Excellent Category

\begin{tabular}{ccc}
\hline Trait & $\mathbf{2 0 0 8}$ & $\mathbf{2 0 1 1}$ \\
\hline Clarity & 66 & 84 \\
Mechanics & 80 & 78 \\
Organization & 70 & 80 \\
Style & 64 & 77 \\
\hline
\end{tabular}

Student work improved in three of the four categories. The substantial jumps in clarity and style were encouraging. The content of the memo was to make a recommendation on investing money. Students clearly stated that the client had two options for investing and that the criteria for choosing the two strategies were a present value issue. For the most part students understood that they were writing to a potential client rather than their BFF. The slight decline in mechanics was initially puzzling. However through faculty discussions it seemed that since the raters could now actually understand the content of the document and were receptive to voice control and tone, they could now focus on grammatical mistakes.

In conclusion, the Anisfield School of Business has attempted to improve the communication skills of students by using a holistic approach which was inspired by the WAC movement. Students write in the majority of the core classes focusing on documents relevant to the content of the class. The message to students is clear and universal-writing is important. Instruction on the highly stylized approach to business writing is provided, with repeat educational opportunities. The pedagogy is intentional, relevant and assessable. The writing learning goal, to master five documents, is specific. The chosen documents are germane to the situational nature of business communication and what is taught is what is assessed, rather than assessing students' cumulative aptitude in writing. Finally, based on preliminary assessment, this modest document driven approach has indicated that student writing has improved.

\section{AUTHOR INFORMATION}

Teresa Hutchins, Ph.D., is an Associate Professor of Economics at Ramapo College of New Jersey. She teaches courses in Microeconomics, International Economics and American Economic History. Dr. Hutchins' research has focused on the economic history of the American whaling industry, the benefits of AACSB accreditation for graduates, and the formation of informal credit associations among ethnic immigrants. She is a four-time recipient of the Outstanding Teacher of the year in the Anisfield School of Business. Email: thutchin@ ramapo.edu.

\section{REFERENCES}

Bechard, Bonnie. (1998). Using Writing in the Business Department to Pursue Excellence. Writing Across the Curriculum, 9, 95-104.

Blummer, Jacob S., Eliason, John, and Fritz Francis. (2001). Beyond the Reactive: WAC Programs and Steps

Ahead. Writing Across the Curriculum, 12, 21-3

Daniel, Carter. (2012). How to Improve Student Writing-And Business Education. BizEd, 64-65.

Dana, H., Hancock, C. and Phillips, J. (2011). A Research Proposal To Evaluate the Merits Of Writing Across the Curriculum. American Journal of Business Education, 4(5), 15-20.

Dana, H., Hancock, C. and Phillips, J. (2011). The Future of Business: Merit In Writing Across the Curriculum. American Journal of Business Education, 4(10), 51-58.

Dynan, L., \& Cate, T. (2009). The Impact of Writing Assignments on Student Learning: Should Writing 
Assignments Be Structured or Unstructured? International Review of Economics Education, 8(1), 62-86.

Jameson, Daphne A. (2009) Management Consulting and Teaching: Lessons Learned Teaching Professionals to Control Tone in Writing. Business Communication Quarterly (September 2009): 333-338.

McEwen, Beryl. (2003) Improving the Writing Skills of Business Majors: The Collective Responsibility of all Course and Professors. Proceeding of the 2003 Association for Business Communication Annual Convention. 1-12

Moore, Daniel P. (1994) Exploring Voice in Business Writing. Writing Across the Curriculum, 5, 39-44.

Reiff, Mary Jo. (2002) Teaching Audience Post-Process: Recognizing the Complexity of Audiences in Disciplinary Contexts. The WAC Journal, 13, 100-111. Washington, Melvin. (2014) The Impact of

Writing Assignments In Business Education: Toward A Competitive Advantage In the Workplace. American Journal of Business Education, 7(3), 265-270. 
NOTES 